\title{
Estrogen receptor-alpha gene Xbal $A>G$ polymorphism influences short-term cognitive decline in healthy oldest-old individuals
}

\author{
Polimorfismo Xbal A > G no gene do receptor do estrogênio-alfa influencia o declínio \\ cognitivo em curto prazo em idosos muito idosos saudáveis \\ Amanda Caroline Silva Chaves ${ }^{1}$, Vanessa Gomes Fraga ${ }^{1}$, Henrique Cerqueira Guimarães², Antonio Lucio \\ Teixeira², Maira Tonidandel Barbosa², Maria das Graças Carvalho', Ana Paula Lucas Mota', leda de Fátima \\ Oliveira Silva', Paulo Caramelli², Karina Braga Gomes', Patrícia Nessralla Alpoim
}

\begin{abstract}
This prospective study aimed to evaluate the influence of the -351A/G Xbal polymorphism in the estrogen receptor-alpha (ESR-1) gene on global cognitive scores of a community sample of healthy oldest-old individuals within one year of follow up. Methods: The individuals were categorized in two groups according to the presence or absence of cognitive decline. Cognitive data were related to genetic information. Results: The Xbal -351 AA genotype was more common among cognitive decliners, while -351G allele carriers showed cognitive stability or improvement. Conclusion: These results suggest that ESR-1 could be associated with one-year cognitive decline in healthy oldest-old individuals, since the estrogen pathway may be involved with neuroprotection, even in healthy brain aging.
\end{abstract}

Keywords: estrogen receptor alpha; polymorphism, genetic; aging; cognition.

RESUMO

Neste estudo prospectivo foi avaliada a influência do polimorfismo -351A/G Xbal do gene do receptor de estrogênio alfa (ESR-1) sobre o desempenho cognitivo global em idosos muito idosos ( $\geq 75$ anos) saudáveis durante um ano. Métodos: Os indivíduos foram divididos em dois grupos de acordo com a presença ou ausência de declínio cognitivo. Dados cognitivos foram relacionados à informação genética. Resultados: 0 genótipo Xbal -351 AA foi mais comum entre indivíduos que apresentaram declínio cognitivo, enquanto carreadores do alelo -351G demonstraram estabilidade ou melhora cognitiva. Conclusão: Estes resultados sugerem que ESR-1 poderia estar associado ao declínio cognitivo em curto prazo em idosos saudáveis, possivelmente por meio de propriedades neuroprotetoras do estrogênio, mesmo em cérebros idosos saudáveis.

Palavras-chave: receptor alfa de estrogênio; polimorfismo genético; envelhecimento; cognição.

Global aging is a challenging reality of this century. In 2010, there were 576 million people aged 65 years and over, worldwide. The expectation for 2050 is that this number will triple, reaching 1.5 billion people ${ }^{1}$. It is important to note that the highest population aging rates occur in developing countries. It is expected that between 2010 and 2050 the number of older people in developing countries will grow around $250 \%$, while in developed countries the rate will be $71 \%^{1}$. Notably, the change in aging is rising: a child born in Brazil in 2015 has a life expectancy 20 years longer than Brazilians who were born just 50 years ago ${ }^{2}$.

The maintenance of cognitive skills is fundamental for preservation of autonomy and quality of life among elderly individuals. Age-associated cognitive decline is characterized by changes in attention regulation, processing speed and memory capacity ${ }^{3}$. Cognitive decline is one of the most feared aspects of old age. It is also the costliest, in terms of financial, personal and social burdens ${ }^{3}$.

\footnotetext{
'Universidade Federal de Minas Gerais, Faculdade de Farmácia, Departamento de Análises Clínicas e Toxicológicas, Belo Horizonte MG, Brasil; ¿Universidade Federal de Minas Gerais, Faculdade de Medicina, Departamento de Clínica Médica, Belo Horizonte MG,Brasil.

Correspondence: Patrícia Nessralla Alpoim; Faculdade de Farmácia, Universidade Federal de Minas Gerais; Avenida Antônio Carlos, 6627 ; $31270-901$ Belo Horizonte MG, Brasil; E-mail: patnessralla@yahoo.com.br

Conflict of interest: There is no conflict of interest to declare.

Support: Fundação de Amparo à Pesquisa de Minas Gerais (FAPEMIG), Conselho Nacional de Desenvolvimento Científico e Tecnológico (CNPq) and Coordenação de Aperfeiçoamento de Pessoal de Nivel Superior (CAPES). ALT, MGC, PC and KBG are grateful to CNPq Research Fellowship (PQ).

Received 28 January 2016; Accepted 21 November 2016.
} 
Normal aging is characterized by some impairment in cognitive performance, which is insufficient to cause dependence. Mechanisms have been proposed as causes of this decline, such as a decrease of brain size and reduction in neurons and synapse counts ${ }^{4}$. Other candidates include oxidative stress, telomere attrition, hormonal dysregulation and immunosenescence ${ }^{5}$. However, a lack of understanding about the physiopathology of cognitive aging remains. Since cognition is a core feature associated with functional performance in senescence, knowledge about mechanisms and strategies for its preservation is crucial.

The estrogen receptor-alpha(ESR-1) belongs to the nuclear hormone receptor superfamily and acts as a ligand-activated transcription factor. The human ESR-1 gene is located on the long arm of chromosome 6 (6q25.1) and contains eight exons separated by seven intronic regions ${ }^{6}$. The ESR-1 is widely expressed in the female genital tract, however, it is also found in the kidneys, liver, brain, heart and most immunologic system cells ${ }^{7}$. Estrogen receptors are located in the brain, especially in regions involved in learning and memory, such as the hippocampus and amygdala ${ }^{8}$. The main polymorphism in the ESR-1 gene is located in intron 1 and consists of the $-351 \mathrm{~A} / \mathrm{G}$ substitution (rs9340799, XbaI A > G), which creates a restriction site for the $X b a \mathrm{I}$ enzyme ${ }^{9,10}$. A possible functional mechanism attributed to this polymorphism of the ESR1 gene includes a change in the mRNA processing, producing different variants or isoforms of the protein with impairment of its function. Moreover, estrogens are important in maintaining brain function in regions typically affected by Alzheimer's disease $(\mathrm{AD})$, thus variations in estrogen exposure over a lifetime may affect cognitive decline associated with $\mathrm{AD}^{11}$.

The aim of this study was to evaluate whether genotypes and alleles of XbaI polymorphism in the ESR1 gene are associated with short-term cognitive decline observed in healthy oldest-old individuals from a previous community-based study.

\section{METHODS}

\section{Study design}

This prospective investigation was conducted with a subgroup of participants from the Pietà study, a population-based investigation on brain aging in subjects aged 75+ years from Caeté city, Brazil. Baseline characteristics of the sample, diagnostic criteria and methods are described elsewhere ${ }^{12}$.

\section{Subjects}

A total of 28 cognitively healthy participants (14 men and 14 women) from the Pietà study were included in the present analysis. Absence in cognitive impairment or dementia was ascertained by standard criteria and consensus discussions among clinical investigators. All cognitively healthy individuals participated of cognitive evaluations in 2008 and 2009 and donated a peripheral blood sample for genetic analysis. All participants or their legal representatives signed the written informed consent and the study protocol was approved by the Ethics Committee of the Federal University of Minas Gerais.

\section{Cognitive evaluation}

In this study, 52 cognitively healthy individuals were genotyped for the XbaI A > G polymorphism, but only 28 were evaluated in cognitive follow-up assessments. The cognitive evaluation of the 28 elderly individuals [median age (IQ) $=78$ (5) years] was performed through brief cognitive tests, including the Mini-Mental State Examination (MMSE), animal category fluency test, and picture drawings memory test, with learning and delayed recall phases. The association of the MMSE and these brief cognitive tests is useful for discriminating healthy individuals, and those with dementia in Brazilian epidemiological studies ${ }^{13}$. All cognitive tests were administered twice, within a one-year interval, and were normalized by the participant's schooling level. The $\mathrm{Z}$ scores derived from the cognitive tests were used to calculate a global cognitive score. The individuals were then categorized in two distinct groups according to the difference between the global cognitive scores obtained in 2008 and in 2009: decliners, those who showed short-term cognitive decline; and non-decliners, those who demonstrated short-term stability or even improvement in cognitive abilities on follow-up evaluation.

\section{Molecular analyses}

Polymorphism genotyping was performed in DNA extracted from peripheral blood, collected in tubes with EDTA (Vacuette ${ }^{\mathrm{TM}}$ ) using Biopur (Biometrix ${ }^{\mathrm{TM}}$ ). Genotyping of the $\mathrm{XbaI} A>\mathrm{G}$ was performed through PCR-RFLP using the restriction enzyme $X b a \mathrm{I}$ (Fermentas ${ }^{\mathrm{TM}}$ ) and electrophoresis in polyacrylamide gel $6 \%$.

\section{RESULTS}

The main results for cognitive evaluations are shown in the Table. We found that individuals with XbaI AA genotype were more frequent in the cognitive decliner group $(p=0.037)$.

Table. Short-term cognitive outcome in cognitively healthy participants according to Xbal A > G genotype. Variables expressed in $n(\%)$.

\begin{tabular}{lccc} 
SNP Xbal A>G & $\begin{array}{c}\text { Decliners } \\
(n=13)\end{array}$ & $\begin{array}{c}\text { Non-decliners } \\
(n=15)\end{array}$ & p-value* \\
\hline$G G$ & $0(0.0)$ & $2(26.7)$ & \\
GA & $0(0.0)^{+}$ & $4(13.3)^{++}$ & $0.037^{*}$ \\
AA & $13(100.0)^{++}$ & $9(60.0)^{+}$ & \\
GG & $0(0.0)$ & $2(13.3)$ & 0.484 \\
A carriers & $13(100.0)$ & $13(86.7)$ & \\
AA & $13(100.0)^{++}$ & $9(66.7)^{+}$ & \\
G carriers & $0(0.0)^{+}$ & $6(33.3)^{++}$ & $0.018^{*}$ \\
\hline
\end{tabular}

* significant, $\chi 2$ test. + less frequent ++ more frequent. A carriers: genotype $A A+G A ; G$ carriers: genotype GG + GA; SNP: Single Nucleotide Polymorphism. 
Additionally, XbaI G allele carriers more frequently showed cognitive stability or improvement $\left(\mathrm{OR}=1.667, \mathrm{CI}_{95 \%}=1.103-2.519\right.$; $\mathrm{p}=0.018)$ compared to carriers of the A allele. Logistic regression analysis confirmed that these findings were independent from age, sex and the presence of the ApoE $\varepsilon 4$ allele (all $p>0.05$ ).

\section{DISCUSSION}

Our findings indicated that the genetic variant XbaI A $>G$ may have an impact on cognitive performance in cognitively normal aging. Some hypotheses for the functional significance of this polymorphism shall be discussed. Cheng et al. ${ }^{14}$ reported that ERS-1 polymorphisms might influence the gene expression and affect estrogen function. Given its location, 351 bp upstream from the start of exon 2, a mechanism including changes on ESR-1 expression via altered binding of transcription factors and influence on alternative splicing of the ESR- 1 gene has been suggested ${ }^{15}$. Such activity appears to be influenced by the genotype at the time of enhancer activity of the $\mathrm{G}$ allele when compared to the A allele. In the present study, our results corroborate this hypothesis, as the elderly participants carrying the $\mathrm{G}$ allele remained stable or showed improvement on cognitive evaluations. As well, several studies have already found an association between the A allele and increased risk of developing $\mathrm{AD}^{16,17,18}$. Usui et al. ${ }^{19}$ found a marginal association between the A allele of XbaI and an increased risk for $\mathrm{AD}$ in elderly Japanese men and women. Similarly, male Italian old individuals with XbaI AA genotype showed an increased risk for $\mathrm{AD}^{20}$.

Amantea et al. ${ }^{11}$ demonstrated that estrogen reduces cell death induced by exocitotoxic stimulation in neuronal cultures. Additionally, Xu et al. ${ }^{21}$ proposed that ERS-1 acts as a transcriptional factor that regulates the gene expression and function by interacting with regulatory regions of target genes. Moreover, some neuroprotective actions such as growth and survival of cholinergic neurons, increased cholinergic activity and antioxidant properties have been attributed to estrogen in pathological contexts ${ }^{22}$. It was also verified that physiological concentrations of estrogen reduce in vitro $\beta$-amyloid peptide $^{11}$. Therefore, estrogen decreases the risk for the development of $\mathrm{AD}$. Here, we suggest that the estrogen pathway may be involved in neuroprotection, even in healthy brain aging.

Finally, we suggest that the genetic variant XbaI A > G may exert a positive impact on cognitive performance in cognitively healthy aging. Methodological limitations need to be considered, such as the absence of estrogen levels data and the small sample size. However, we were unable to find another similar study that has investigated the influence of XbaI A > G on cognitive decline in the healthy oldest-old. Therefore, our preliminary data may motivate more robust studies designed for this purpose.

\section{References}

1. World Health Organization; National Institute of Aging (US). Global health and ageing. Washingon, DC: National Institute of Aging; 2011.

2. Nitrini R, Caramelli P, Bottino CM, Damasceno BP, Brucki SM, Anghinah R. [Diagnosis of Alzheimer's disease in Brazil: cognitive and functional evaluation. Recommendations of the Scientific Department of Cognitive Neurology and Aging of the Brazilian Academy of Neurology]. Arq Neuropsiquiatr. 2005:63(3A):720-7. Portuguese. https://doi.org/10.1590/S0004-282X2005000400034

3. Deary IJ, Corley J, Gow AJ, Harris SE, Houlihan LM, Marioni RE et al. Age-associated cognitive decline. Br Med Bull. 2009;92(1):135-52. https://doi.org/10.1093/bmb/ldp033

4. Desai AK, Grossberg GT, Chibnall JT. Healthy brain aging: a road map. Clin Geriatr Med. 2010;26(1):1-16. https://doi.org/10.1016/j.cger.2009.12.002

5. Mariani E, Polidori MC, Cherubini A, Mecocci P. Oxidative stress in brain aging, neurodegenerative and vascular diseases: an overview. J Chromatogr B Analyt Technol Biomed Life Sci. 2005;827(1):65-75. https://doi.org/10.1016/j.jchromb.2005.04.023

6. Parker MG, Arbuckle N, Dauvois S, Danielian P, White R. Structure and function of the estrogen receptor. Ann NY Acad Sci. 1993;684:119-26. https://doi.org/10.1111/j.1749-6632.1993.tb32276.x

7. Couse JF, Lindzey J, Grandien K, Gustafsson JA, Korach KS. Tissue distribution and quantitative analysis of estrogen receptor-alpha (ERalpha) and estrogen receptor-beta (ERbeta) messenger ribonucleic acid in the wild-type and ERalpha-knockout mouse. Endocrinology. 1997:138(11):4613-21. https://doi.org/10.1210/endo.138.11.5496

8. Shughrue PJ, Lane MV, Merchenthaler I. Comparative distribution of estrogen receptor-alpha and -beta mRNA in the rat central nervous system. J Comp Neurol. 1997;388(4):507-25. https://doi.org/10.1002/ (SICI)1096-9861(19971201)388:4<507::AID-CNE1>3.0.CO;2-6
9. Schuit SC, Jong FH, Stolk L, Koek WN, Meurs JB, Schoofs MW et al. Estrogen receptor alpha gene polymorphisms are associated with estradiol levels in postmenopausal women. Eur J Endocrinol. 2005;153(2):327-34. https://doi.org/10.1530/eje.1.01973

10. Maruyama H, Toji H, Harrington CR, Sasaki K, Izumi Y, Ohnuma T et al. Lack of an association of estrogen receptor alpha gene polymorphisms and transcriptional activity with Alzheimer disease. Arch Neurol. 2000;57(2):236-40. https://doi.org/10.1001/archneur.57.2.236

11. Amantea D, Russo R, Bagetta G, Corasaniti MT. From clinical evidence to molecular mechanisms underlying neuroprotection afforded by estrogens. Pharmacol Res. 2005;52(2):119-32. https://doi.org/10.1016/j.phrs.2005.03.002

12. Caramelli P, Barbosa MT, Sakurai E, Santos EL, Beato RG, Machado JC et al. The Pietà study: epidemiological investigation on successful brain aging in Caeté (MG), Brazil. Methods and baseline cohort characteristics. Arq Neuropsiquiatr. 2011;69(4):579-84. https://doi.org/10.1590/S0004-282X2011000500002

13. Nitrini R. Testes neuropsicológicos de aplicação simples para o diagnóstico de demência. Arq Neuropsiquiatr; 1994;52(4):457-65. https://doi.org/10.1590/S0004-282X1994000400001

14. Cheng D, Liang B, Hao Y, Zhou W. Estrogen receptor $\alpha$ gene polymorphisms and risk of Alzheimer's disease: evidence from a meta-analysis. Clin Interv Aging. 2014;9:1031-8. https://doi.org/10.2147/CIA.S65921

15. Albagha OM, McGuigan FE, Reid DM, Ralston SH. Estrogen receptor alpha gene polymorphisms and bone mineral density: haplotype analysis in women from the United Kingdom. J Bone Miner Res. 2001;16(1):128-34. https://doi.org/10.1359/jbmr.2001.16.1.128 
16. Brandi ML, Becherini L, Gennari L, Racchi M, Bianchetti A, Nacmias B et al. Association of the estrogen receptor alpha gene polymorphisms with sporadic Alzheimer's disease. Biochem Biophys Res Commun. 1999;265(2):335-8. https://doi.org/10.1006/bbrc.1999.1665

17. Isoe-Wada K, Maeda M, Yong J, Adachi Y, Harada H, Urakami Ket al. Positive association between an estrogen receptor gene polymorphism and Parkinson's disease with dementia. Eur J Neurol. 1999;6(4):431-5. https://doi.org/10.1046/j.1468-1331.1999.640431.x

18. Janicki SC, Park N, Cheng R, Clark LN, Lee JH, Schupf N. Estrogen receptor $\alpha$ variants affect age at onset of Alzheimer's disease in a multiethnic female cohort. Dement Geriatr Cogn Disord. 2014;38(3-4):200-13. https://doi.org/10.1159/000355559

19. Usui C, Shibata N, Ohnuma T, Higashi S, Ohkubo T, Ueki A et al. No genetic association between the myeloperoxidase gene -463 polymorphism and estrogen receptor-alpha gene polymorphisms and Japanese sporadic Alzheimer's disease. Dement Geriatr Cogn Disord. 2006;21(5-6):296-9. https://doi.org/10.1159/000091437

20. Corbo RM, Gambina G, Ruggeri M, Scacchi R. Association of estrogen receptor alpha (ESR1) Pvull and Xbal polymorphisms with sporadic Alzheimer's disease and their effect on apolipoprotein E concentrations. Dement Geriatr Cogn Disord. 2006;22(1):67-72. https://doi.org/10.1159/000093315

21. Xu CY, Jiang ZN, Zhou Y, Li JJ, Huang LM. Estrogen receptor $\alpha$ roles in breast cancer chemoresistance. Asian Pac J Cancer Prev. 2013;14(7):4049-52. https://doi.org/10.7314/APJCP.2013.14.7.404

22. Toran-Allerand CD, Miranda RC, Bentham WD, Sohrabji F, Brown TJ, Hochberg RB et al. Estrogen receptors colocalize with low-affinity nerve growth factor receptors in cholinergic neurons of the basal forebrain. Proc Natl Acad Sci USA. 1992;89(10):4668-72. https://doi.org/10.1073/pnas.89.10.4668 